УДК 141.7

Н.А. Ємець, к. філос. н., доцент,

о.є. Мельник, к. філос. н., доцент

\section{СПІВВІДНОШЕННЯ ДУХОВНОСТІ Й ЖИТТЕВОЇ КОМПЕТЕНТНОСТІ ОСОБИСТОСТІ: СУЧАСНІ ЦИВІЛІЗАЦІЙНІ ВИКЛИКИ}

Розглядається ціннісно-смислова визначеність життєдіяльності особистості, що лежить в основі буттєвого вибору людини. Буттєвий вибір аналізується через призму співвідношення буттєвої компетентності і буттєвої мудрості. $B$ умовах сучасних цивілізаційних ризиків такий підхід сприяє формуванню гідноі життєвої позиції людини.

Ключові слова: сила волі, сила духу, самоствердження, воля як свобода, відповідальність як "внутрішня потреба", одухотворені душевні почуття, одухотворені естетичні почуття.

Н.А. Ємець, О.Є. Мельник. Соотношение духовности и жизненной компетентности личности: современные цивилизационные вызовы

Рассматривается ценностно-смысловая определённость жизнедеятельности личности, которая находится в основе бытийного выбора человека. Бытийный выбор анализируется через призму соотношения бытийной компетентности и бытийной мудрости. В условиях современных цивилизационных рисков такой подход способствует формированию достойной жизненной позиции человека.

Ключевые слова: сила воли, сила духа, самоутверждение, воля как свобода, ответственность как "внутренняя необходимость", одухотворённые душевные чувства, одухотворённые эстетические чувства.
N.A. Yemets, O.E. Melnyk. The relation between spirituality and a person's life competence: modern civilizational chalanges.

Abstract. The value semantic orientation of a person's life, which is the basis of a person's life choice, is considered. The life choice is analyzed through the prism of the relation between life competence and life wisdom. Taking modern civilizational risks into account, this approach contributes to the formation of a decent human life position.

Keywords: will power, fortitude, selfaffirmation, freedom as liberty, responsibility as "internal need", inspired emotional feelings, inspired aesthetic sense.

Актуальність теми дослідження. Становище людини в сучасному світі не $€$ однозначним. 3 одного боку, внаслідок гуманітарно-інформаційної революції, що відбулася на зламі тисячоліть, зростає роль особистості як режисера та актора своєї індивідуальної життєвої долі. 3 іншого боку, сучасну людину можна схарактеризувати як таку, що "загубилася у власному житті”, тобто втратила певну ціннісно-смислову форму власного буття. Позбавлена міфічного, метафізичного, позитивного й навіть широкого культурного визначення, постать людини перетворюється на рухливу картинку у фотографічному розумінні цього слова. Ї̈̈ "Я" стає порожньою оболонкою, що гойдається на хвилях простору та часу без фіксації і без орієнтирів. Отже, проблема життєвої компетентності особистості як вміння вбирати своє життя у певну духовну форму постає як одна з найактуальніших у проблемному полі індивідуального буття людини у сучасному суперечливому світі.

Аналіз останніх досліджень і публікацій. У сучасній філософській антропології першим необхідним компонентом життєвої компетентності визначається ціннісно-смислова визначеність життєдіяльності особистості. Людське життя роз- 
глядається, як ризик рішень і здійснень, як постійний вибір, як буттєвий вибір, тобто, як вибір між різними моделями життя, між різними моделями людини. Н.Абаньяно, М.Рідель, О.Больнов та інші сходяться на думці, що такий буттєвий вибір потребує й відповідної буттєвої компетентності як певної буттєвої мудрості, яка $\epsilon$ не просто здоровим глуздом, а вмінням вбирати своє життя у споріднену собі та гідну людини форму. В.Табачковський, вважає, що усунення морально-етичних передумов з людської діяльності не тільки спотворює духовний абрис самої людини, руйнує її власне життя, але й становить загрозу для зовнішнього світу (інших людей, суспільства, природи). В.Шинкарук та І.Ільїн називають найпершою особистісною якістю, яка забезпечує антропологічну визначеність, - духовність, як вправи з мудрістю, які $\epsilon$ завжди непевними, завжди поновлюваними.

Виділення недосліджених частин загальної проблеми. 3 огляду на поглиблення та розширення глобалізаційних процесів, нового смислового значення набуває духовність людини. В цих умовах формується необхідність дослідження духовності як форми життєвого самовизначення людини, яка скеровує, інспірує всі духовні пошуки людини і $\epsilon$ невід'ємним компонентом життєвої компетентності. Процес життєтворчості не є результатом суто раціональних зусиль і не може бути забезпечений лише наявністю відповідної системи знань. Життєтворчість, як і будь-яка інша форма творчої діяльності, для свого здійснення потребує не тільки інтелектуальних зусиль, але й певного інспіруючого натхнення, інтуїтивного прозріння, вольової наполегливості та розвинених почуттів, зокрема естетичних. Інспіруюче натхнення та інтуїтивне прозріння у сфері життєтворчості зумовлені духовністю особистості. Духовність $\epsilon$ тим джерелом, яке підживлює вольову наполегливість людини щодо здійснення процесу життєтворчості.

Постановка завдання. В нашій розвідці ми замислимося над тим, що надає людині сил для того, щоб чинити опір тискові несприятливих життєвих обставин, сконцентрувати свої помисли та дії на розв'язанні певної життєвої проблеми, вистояти, не зламатися за умов життєвої кризи.

Виклад основного матеріалу. Відкриття та розвиток у собі духовності надає особистості внутрішньої автономії, відносної неза-лежності від життєвих обставин і можливості піднестися над ними, знайти таку внутрішню точку опертя та чинення спротиву, яка дозволить сконструювати власний життєвий світ, зберегти цілісність і гідність, певну цілеспрямованість волі за будь-яких обставин. Людина не відчуває душевного задоволення і радості, якщо вона занурена у потік буденного життя і не може знайти у ньому нічого особливо цінного. Такий стан може тривати тільки за відносно сприятливого перебігу життєвих подій. I навіть за цих умов він має надзвичайно трагічні життєві наслідки. Людина, “загублена у банальності повсякдення”, ніколи не може розпрямитися, вона розчавлена життєвими обставинами, не бачить власних життєвих обріїв і, відповідно, ніколи не може реалізувати свою справжню природу. Вона не має того необхідного життєвого натхнення, яке може спрямувати її волю поза межі цих банальностей, розірвати їхні ланцюги й вивести ії на шлях смисложиттєвих здійснень.

Вольовий акт постає як згусток духу. Ця духовна зумовленість конституює $\mathrm{i}$ спрямовує волю як необхідну особистісну здатність, формує особистісний стрижень, який позначають поняттям "сила волі”. Іншими словами, у внутрішньому особистому просторі сила волі набуває характеру сили духу. Але у цьому контексті слід звернути увагу на те, що дух люди- 
ни може зростати на двох відмінних підгрунтях - етичному та естетичному. Отже, і сила духу може мати амбівалентний характер - поставати як внутрішня моральна сила та як “демонічний естетизм”. Сила духу, набуваючи форми “демонічного естетризму”, інспірує прагнення людини до нічим не обмеженого самоствердження, намагання стати самодостатньою “творчою основою" [12].

Сила волі, позбавлена морально-етичних засад, обертається на розгул пристрастей та свавілля засадово аморальної особистості. Дух людини, переходячи межу між добром та злом, доброю та злою волею, між святістю та злочином, стає силою, деструктивною щодо життя особистості. На думку В.Табачковського,: “Позаяк практична життєдіяльність людини $є$ амбівалентною, у разі втрати нею моральних горизонтів вона стає цинічною" [13].

Отже, моральні засади лише й уможливлюють вихід людини за межі безпосередніх обставин власної життєдіяльності, перетворюють людину на свідомого та відповідального суб'єкта життєдіяльності, роблять людську волю “прозрілою”. Тільки “прозріла" воля може звільнити людину від примхливої гри ії̈ бажань, часто-густо суто тваринних потягів. Тільки “зряча" воля стає невід'ємним компонентом життєвої компетентності і во-дночас необхідною умовою свободи волі, або, інакше, волі як свободи.

Свобода - ще один важливий компонент життєвої компетентності - нерозривно сполучена з духовністю. У сучасній філософії свободу розглядають в екзистенційному вимірі. Особливістю екзистенційного осмислення свободи $€$ те, що їі пов'язують з найважливішими аспектами людського самовизначення, 3 особистісним пошуком і самовизначенням, 3 конструюванням власного “Я”, а також моделей взаємовідносин зі світом. Свобода потребує від суб'єкта як утвер- дження самого себе всупереч зовнішній детермінації, так і постійного подолання власної обмеженості, яка успадкована від природи та свого минулого. Свобода - це вибір. Вона - не миттєвий акт, а безперервність зусилля, яке постійно понов-люється за сприятливих чи несприятливих обставин. Бути вільним - це означає бути вірним самому собі, не зраджувати своєму призначенню, стикаючись з опором світу і рятуючи солідарність між людьми. Розуміння свободи - таке саме розуміння, яке людина має про себе та про своє призначення у світі [2]. Виходячи з цих міркувань, ми можемо осягнути життєтворчість як процес набуття, утвердження та реалізації особистістю свободи. Але свободи не як свавілля, а як такої, що має певні міцні духов-но-моральні підвалини. На думку Н.Абаньяно: “Вибір свободи миттєво позбавляє людину всіх вагань життя, позбавленого будь-якого домінуючого інтересу, й повертає їй всю повноту їі енергії. Людина стає вільною для здійснення свого завдання; іï вже не відволікають дедалі нові бажання, вона не закинута у світ без будь-якої спрямованості й не губиться у незначних подіях. Вона живе зосереджено, єдиним домінуючим інтересом і зводить до цього інтересу як до міри та фундаментального критерію все багатоманіття подій" [1].

У межах свободи можна виявити не тільки екзистенційний, але й комунікативний вимір. У такому ракурсі свобода нерозривно сполучена з відповідальністю і також грунтована на духовно-моральних підвалинах. Таку особливість свободи послідовно й переконливо обгрунтовує Манфред Рідель. Йдучи за I. Кантом, він доводить, що свобода $\epsilon$ не свободою від, а свободою серед законів - закономірностей, які можна вільно осмислювати. Звідси реальна свобода постає як свобода дій, обмежена діючими закономірностями природи та соціуму. Оцінюючи наші дії та вчинки як "добрі" 
або “злі", ми переходимо у царину родових визначень реальної свободи. Саме тоді, коли ми говоримо про людські вчинки, що вони "могли б відбутися або ж ні", ми розглядаємо наше воління як вільне. Це й $є$ фактом судження людського розуму взагалі, до якого включена свобода в її комунікативному розумінні [14].

Через сполучення свободи з принципом оцінки вчинків ми опиняємось у царині відповідальності як "внутрішньої потреби”, як “вимоги комунікативного порядку". Адже "на відміну від поняття обов'язку, на якому грунтується категоричний імператив і яке несе у собі сенс “ти повинен”, поняття відповідальності охоплює взаємні відносини та вимоги, на які ми покладаємось як на первинні моральні феномени" [6]. Звідси випливає висновок, що свобода і відповідальність взаємно пов'язані поняття, де останнє вказує на межі першого.

Значення відповідальності як духовного феномена в структурі життєвої компетентності можна слідом за М.Ріделем схарактеризувати так: “Відповідальність людини як окремої, самостійної особи за свої дії та вчинки - умова можливості комунікативного ладу, який історично має за підгрунтя спільну практику та форми життя" [11]. Моральна відповідальність має водночас особисту й соціальну основу і припускає належність до інституцій. Вона полягає не в ігноруванні існуючого стану речей, а в можливому, в його межах, спілкуванні з іншими людьми. "Основа" визначеної таким чином відповідальності полягає перш за все у повазі людської гідності особи, а не інституцій.

Не менше значення в структурі життєвої компетентності, ніж вільна та відповідальна воля, мають духовні чи одухотворені почуття, що складають душевний пласт особистості. Якщо духовність відкриває для особистості цінності творчості, свободи, буттєві обрії досконалості та вічності, висуває вимоги відповідально- сті, то душевність як емоційно-моральне ставлення до себе як цінності і до іншого як до самого себе відкриває цінності переживання, обрії спілкування і почуттів у просторі повсякдення. Але життєва компетентність потребує не просто розвитку душевних почуттів, а саме почуттів, які “запліднені" духом, які набули певної духовної визначеності. Надзвичайно влучними у цьому контексті $є$ міркування І.Ільїна. Він наполегливо доводив, що там, де духовних неможливостей немає, а душевні можливості є безконечними, відбувається розпад особистості, перетворення її на жертву дурних пристрастей та обставин. Такий стан особистості він позначив поняттям "духовної дефективності”. Російський філософ характеризує цей стан так: “Людина, духовно дефективна 3 дитинства, може виробити у себе навіть особливий душевний уклад, який при поверховому спостереженні може бути прийнятий за "характер", і особливі погляди, які помилково приймають за "переконання”. Насправді вона, безпринципна та безхарактерна, залишається завжди рабом своїх дурних пристрастей, полоненим вироблених душевних механізмів, які тримають її і всесильні в її житті, позбавлені духовних вимірів і складають криву іï потворної поведінки. Вона не чинить їм опору, але виворотливо насолоджується їхньою грою, примушуючи наївних людей приймати ії̈ злу одержимість за волю, iї інстинктивну хитрість за розум, поривання її злих пристрастей за почуття" [5].

Людська душа, не скерована духом, сформованим на етичних засадах, залишається, за висловом К. Юнга "темною пучиною вод", пучиною, яка може вийти 3 “берегів" і цілком поглинути людину, зруйнувати ії особистість та, врешті-решт, життя.

Розвиток одухотворених душевних почуттів $\epsilon$ дуже важливою складовою процесу життєтворчості й тому, що життя людини не переживається у вакуумі, а пе- 
редбачає постійне спілкування, взаємодію з іншими людьми, налагодження міцних і плідних для особистості духовних контактів, що $є$ умовою подолання самотності. Значення подолання самотності у життєвому плані зумовлене тим, що “людина не може реалізувати себе інакше, ніж у відносинах з іншими людьми і світом; тому будь-яка спроба її самореалізації, будь-яка спроба осягнути буття та оволодіти ним неминуче зміцнює її зв'язки зі світом речей та іншими людьми" [1].

Подолання власної окремішності у світі, впізнавання себе та іншого як цінності, особистісне зростання потребують любовного ставлення до світу (зовнішнього та внутрішнього). Любовне ставлення до світу - це необхідна складова життєвої компетентності як здатності особистості пережити себе та Інше як цінність. Любов - це плідна сила людського життя, вона відкриває й народжує прекрасне у людині та у світі. Цю життєдайну силу любові як осереддя духовності можна, за словами В.Шинкарука, схарактеризувати так: “надзвичайно важливе значення почуттів любові полягає в їх здатності перетворювати знання, ідеї, образи певних цінностей в ідеали. Ідея добра стає моральним ідеалом, коли вона животвориться моральним почуттям, коли служіння добру приносить найбільшу моральну радість, а зрада - горе, муки сумління... Отже, любов $є$ глибинною основою духовності, а відтак і всього духовного життя людини. Це те, що підносить її над усіма марнотами сьогодення до вищих, справді людських, а тому священних поривань" [17]. Тому наявність у житті любові в різних її формах завжди вносить у життя особистості відчуття піднесеності, духовної радості, значущості того життєвого моменту, який зараз переживається, надає буденності виміру святковості. Це й примушує людину знов і знов подумки повертатися до любовних переживань, прагнути їх упродовж усього життя. Звідси життєва компе-тентність потребує розвитку здатності до переживання любові у різних ії формах, вміння відшукувати гідні любові предмети, які мають справжній особистісний смисложиттєвий сенс. Від служіння предмету любові особистість дістає найвищу насолоду, від втрати - муки та страждання. Але якщо предмети любові не $\epsilon$ гідними життєвого служіння, вони можуть зруйнувати особистість та їі життя.

Любовне ставлення до світу (зовнішнього та внутрішнього) завжди сполучене з такими почуттями, як віра та надія. Віра та надія - необхідні засоби для існування, здійснення, реалізації любові - також $є$ необхідними складовими життєвої компетентності. В.Шинкарук пропонує таке визначення віри: «Віра - форма і спосіб сприйняття соціальної інформації, норм, цінностей та ідеалів суспільного життя, коли вони, не будучи даними власним практичним чи пізнавальним досвідом, прий-маються як очевидні факти чи характеристики об'єктивної дійсності, сущого й належного; засіб освоєння досвіду попередніх поколінь, сприйняття сподівань, очікувань та надій щодо майбутнього" [19]. У цьому визначенні наголос зроблено на характеристиці віри як певної форми сприйняття істини, вона постає як віра-вірогідність. Ця форма віри, безперечно, $є$ дуже важливою для процесу життєтворчості, оскільки людина у власному житті завжди так чи інакше звертається до “досвіду інших, які пережили буття” і саме з цього обирає для себе ті цінності та смисли, моделі поведінки та життєво необхідну інформацію, яка уявляється для неї вірогідною. Але вірити - це не те ж саме, що визначати за істину. У вірі розкривається, знаходить прояв щось таке, що має для нас внутрішню, вільно визнану переконливість і цінність, "віра є ніщо інше, як головне і провідне тяжіння людини, яке визначає її життя, її погляди, її прагнення та вчинки" [7]. 
Отже, віра - це всевладне внутрішнє духовне тяжіння особистості. Можна навіть сказати, що життя особистості $\epsilon$ реалізацією та демонстрацією того, у що вона вірить. Але віра як особистісне почуття може мати різні форми. Людина може "нехтувати своєю вірою, залишати ïi напризволяще, пронизувати її передсудами та забобонами, перетворювати її на сліпий та руйнівний фанатизм чи відводити їй один куток своєї душі, до того ж найбільш боягузливий та облудний, вона може зраджувати своїй вірі за розрахунком і гендлювати нею. Але в одному людині відмовлено, одного вона не може, а саме - жити без віри" [8]. Отже, життєва компетентність передбачає не просто наявність віри як невід’ємної складової особистості, а певну якість віри, здатність вибирати предмети, гідні духовної довіри. У площині життєвої компетентності віра постає як форма особистої довіри довіри до себе, Іншого, цінностей, світу, життя загалом. Така віра-довіра стає важливою умовою подолання чужинності, ворожості світу, а звідси - й важливою умовою психологічного комфорту особистості. Крім того, віра і надія як форми сприйняття та переживання майбутнього активізують волю. Без віри і надії людський дух безсилий, так само як без любові він безплідний.

Надія у структурі життєвої компетентності $\epsilon$ необхідним знаряддям бачення життєвої перспективи. В.Шинкарук зазначає, що "надія - це одна 3 форм сприйняття майбутнього, де бажане й життєво необхідне в прийдешньому бачиться й очікується як реальність, що має напевне здійснитись. На відміну від мрії, надія сприймає майбутнє не лише як можливе і тим паче не як вигадку, а як певне, здатне сповнитися, що в самому собі містить сприятливість для настання. Тому ми надіємось" [18].

Плекання надії не тільки уможливлює особистісне бачення власної життєвої перспективи, але й $є$ необхідною умовою самозбереження особистості у ситуації життєвої кризи. Згасання надії на краще перетворює життя на “животіння". Поняття “животіння”, як правило, тлумачать як такий стан, в якому життєві сили особистості зведено майже нанівець. Але на поняття “животіння” можна подивитися й з іншого боку. Це такий стан, коли всі потреби особистості зведені до потреб “живота", але не внаслідок якихось матеріальних труднощів, а внаслідок зневіри у життєвій спроможності надутилітарних, надособових цінностей, внаслідок руйнування смисложиттєвої перспективи. Цей психологічний стан можна схарактеризувати відомим висловлюванням: “Треба брати від життя все, оскільки живемо тільки один раз". Звідси постають і дві психологічні реакції на згасання надії та пов'язаного з цим максимального обмеження життєвих прагнень: глибока депресія або тваринна розгнузданість пристрастей, за якою прихований той самий депресивний стан особистості. Згасання надії, таким чином, постає як руйнування життєвої перспективи внаслідок зневіри у буттєвій можливості досконалості людини та світу, Добра та Справедливості і означає втрату любові до себе й до життя. Плеканню надії може допомогти відкриття та збереження особистістю у собі духовності як певного ціннісно-смислового стрижня власного життєвого світу.

Виходячи з усього зазначеного вище, можна зробити висновок, що віра і надія (в їх сполученні з любов'ю) $є$ найважливішими екзистенціалами духовності сучасної людини, які мають сенс не тільки у межах християнського світогляду, але й $€$ наріжними за умов зростання духовності на етичних засадах. Саме тому триєдність “Віра - Надія - Любов” (незалежно від того, чи має вона релігійну чи то секуляризовану форму) зумовлює та вможливлює процес життєтворчості, а 
тому є необхідною складовою життєвої компетентності.

Особливе місце серед духовних почуттів, які мають принципову життєву значущість, посідає совість. Вона $є$ необхідним знаряддям особистісної саморегуляції, самоконтролю, самокоригування, відповідального ставлення до власного життя та життя загалом. Совість $є$ формою синтезу загального та унікального у житті людини. Совість - це необхідний засіб узгодження “довічного", всезагального морального закону з конкретною ситуацією конкретної людини. Як правомірно зазначає В.Франкл, “життя по совісті - це завжди абсолютно індивідуально-особистісне життя відповідно до абсолютно конкретної ситуації, до всього того, що може визначити наше унікальне та неповторне буття" [16]. Совість завжди враховує конкретність мого особистого буття й робить його індивідуальним. Отже, оволодіння мистецтвом жити безперечно передбачає пробудження та розвиток совісті людини, вкоріненої в глибинах людської духовності.

I, нарешті, ще один дуже важливий компонент життєвої компетентності одухотворені естетичні почуття. Вони збагачують духовне життя людини, оскільки уможливлюють здатність до відчуття, переживання Краси та одержання радості, духовної насолоди від цього. Якщо без моральних горизонтів людина стає цинічною, то без естетичних горизонтів вона ризикує стати фарисеєм, її життєвий світ може перетворитися на “позадзеркалля морального обов'язку", втратити буттєву вкоріненість. Естетичні переживання не просто збагачують наше життя. Без здатності відчувати радість від зустрічі з Прекрасним у собі, в Іншому, у світі неможливе й почуття любові, неможливі й усі інші почуття. 3 цього приводу Г.-Г. Гадамер цілком слушно відзначав, що переживання " $є$ способом буття естетичного": "Естетичне переживання - це не лише один з різновидів переживання, що існує поряд з іншими, але репрезентація самого єства переживання взагалі" [4]. Щоб переконатися в цьому, слід осягнути поняття "прекрасне". Прекрасне, як зазначав ще Аристотель, є міра в усьому. Це гармонія і досконалість. Власне почуття радості значною мірою $є$ естетичним переживанням. Радість у життєвому плані постає як переживання гармонійної узгодженості всіх складових життя, пов'язане 3 відчуттям задоволення від відкриття прекрасного, піднесеного у собі та у світі. Естетичні почуття відкривають для людини ті обрії світу, які неприступні для логічного аналізу.

Висновки та перспективи подальших досліджень. Таким чином, структура життєвої компетентності не обмежується лише сукупністю знань, умінь, навичок, які необхідні для здійснення процесу життєтворчості. Відповідні знання, навички, вміння $є$ дуже важливими складовими життєвої компетентності. Але без наявності такого компонента, як духовність, життєва компетентність буде “сліпою”. Духовність - це ціннісно-смисловий, інтегруючий, інспіруючий, спрямовуючий, якісно визначальний, регулюючий чинник у структурі життєвої компетентності. Життєва компетентність, просвітлена духовністю, включає до своєї структури сумління та відповідальність, одухотворені волю та почуття, прагнення до свободи та творчості, триєдність любові, віри та надії, здатність та потребу відшукувати й переживати прекрасне у світі та житті.

\section{Література}

1. Абаньяно Н. Экзистенция как свобода // Вопросы философии. - М., 1992. - №8. - С. 157

2. Абаньяно Н. Экзистенция как свобода // Вопросы философии. - М., 1992. - №8. - С. 150

3. Больнов О. Ф. Зустріч // Ситниченко Л. А. першоджерела комунікативної філософії. К., 1996. - С. 81 
4. Гадамер Х.- Г. Истина и метод. - М., 1988. C. 115.

5. Ильин И.А. Путь к очевидности. - М., 1993. - С. 11

6. Ильин И.А. Путь к очевидности. - М., 1993. - С. 78 - 79

7. Ильин И.А. Путь к очевидности. - М., 1993. - С. 137

8. Ильин И.А. Путь к очевидности. - М., 1993. - С. 139

9. Ильин И.А. Путь к очевидности. - М., 1993. - С. 304

10. Рідель М. Свобода і відповідальність // Ситниченко Л. А. першоджерела комунікативної філософії. - К., 1996. - С. 81

11. Рідель М. Свобода і відповідальність // Ситниченко Л. А. першоджерела комунікативної філософії. - К., 1996. - С. 82 -83

12. Табачковський В. Г. Вивчення проблеми духовності сьогодні: розрив традиції чи спадкоємність? // Актуальні проблеми духовності: Збірник наукових матеріалів. - Київ; Кривий Ріг, 1997. - Вип. 2. - С. 16

13. Табачковський В. Г. Вивчення проблеми духовності сьогодні: розрив традиції чи спадкоємність? // Актуальні проблеми духовності: Збірник наукових матеріалів. - Київ; Кривий Ріг, 1997. - Вип. 2. - С. 17

14. Табачковський В. Г. Вивчення проблеми духовності сьогодні: розрив традиції чи спадкоємність? // Актуальні проблеми духовності: Збірник наукових матеріалів. - Київ; Кривий Ріг, 1997. - Вип. 2. - С. 100

15. Табачковський В. Г. Вивчення проблеми духовності сьогодні: розрив традиції чи спадкоємність? // Актуальні проблеми духовності: Збірник наукових матеріалів. - Київ; Кривий Ріг, 1997. - Вип. 2. - С. 150

16. Франкл В. Человек в поисках смысла. M., 1990. - C. 98

17. Шинкарук В. І. Поняття культури: філософські аспекти // Феномен української культури: Методологічні засади осмислення. - К., 1996. - С. 32

18. Шинкарук В. I. Поняття культури: філософські аспекти // Феномен української культури: Методологічні засади осмислення. - К., 1996. - С. 40

19. Шинкарук В. І. Поняття культури: філософські аспекти // Феномен української куль- тури: Методологічні засади осмислення. - К., 1996. - С. 41

\section{References}

1. Abaniano N. Эkzystentsyia kak svoboda // Voprosы fylosofyy. - M., 1992. - №8. - S. 157

2. Abaniano N. Эkzystentsyia kak svoboda // Voprosu fylosofyy. - M., 1992. - №8. - S. 150

3. Bolnov 0. F. Zustrich // Sytnychenko L. A. pershodzherela komunikatyvnoi filosofii. - K., 1996. - S. 81

4. Hadamer Kh.- H. Ystyna y metod. - M., 1988. - S. 115.

5. Ylyn Y.A. Put k ochevydnosty. - M., 1993. - S. 11

6. Ylyn Y.A. Put k ochevydnosty. - M., 1993. - S. $78-79$

7. Ylyn Y.A. Put k ochevydnosty. - M., 1993. - S. 137

8. Ylyn Y.A. Put k ochevydnosty. - M., 1993. - S. 139

9. Ylyn Y.A. Put k ochevydnosty. - M., 1993. - S. 304

10. Ridel M. Svoboda i vidpovidalnist // Sytnychenko L. A. pershodzherela komunikatyvnoi filosofii. - K., 1996. - S. 81

11. Ridel M. Svoboda i vidpovidalnist // Sytnychenko L. A. pershodzherela komunikatyvnoi filosofii. - K., 1996. - S. 82 -83

12. Tabachkovskyi V. H. Vyvchennia problemy dukhovnosti sohodni: rozryv tradytsii chy spadkoiemnist? // Aktualni problemy dukhovnosti: Zbirnyk naukovykh materialiv. - Kyiv; Kryvyi Rih, 1997. - Vyp. 2. - S. 16

13. Tabachkovskyi V. H. Vyvchennia problemy dukhovnosti sohodni: rozryv tradytsii chy spadkoiemnist? // Aktualni problemy dukhovnosti: Zbirnyk naukovykh materialiv. - Kyiv; Kryvyi Rih, 1997. - Vyp. 2. - S. 17

14. Tabachkovskyi V. H. Vyvchennia problemy dukhovnosti sohodni: rozryv tradytsii chy spadkoiemnist? // Aktualni problemy dukhovnosti: Zbirnyk naukovykh materialiv. - Kyiv; Kryvyi Rih, 1997. - Vyp. 2. - S. 100

15. Tabachkovskyi V. H. Vyvchennia problemy dukhovnosti sohodni: rozryv 
tradytsii chy spadkoiemnist? // Aktualni problemy dukhovnosti: Zbirnyk naukovykh materialiv. - Kyiv; Kryvyi Rih, 1997. - Vyp. 2. - S. 150

16. Frankl V. Chelovek $\mathrm{v}$ poyskakh smыsla. - M., 1990. - S. 98

17. Shynkaruk V. I. Poniattia kultury: filosofski aspekty // Fenomen ukrainskoi kultury: Metodolohichni zasady osmyslennia. - K., 1996. - S. 32

18. Shynkaruk V. I. Poniattia kultury: filosofski aspekty // Fenomen ukrainskoi kultury: Metodolohichni zasady osmyslennia. - K., 1996. - S. 40

19. Shynkaruk V. I. Poniattia kultury: filosofski aspekty // Fenomen ukrainskoi kultury: Metodolohichni zasady osmyslennia. - K., 1996. - S. 41

Надійшла 15.11.2018.

Бібліографічний опис для цитування:

Ємець Н.А., Мельник О.Є. Співвідношення духовності ц̆ життєвої компетентності особистості: сучасні цивілізаційні виклики / Н.A. Ємець, О. Є.Мельник // Sорhіа Prima: діалог вічного повернення - 2019. - № 1. - С. 81-89.
УДК 14:316:37

M. I. Захаріна, викладач

КОНЦЕПТ «ЦІІСНОЇ ОСОБИСТОСТІ» У ФІЛОСОФСЬКОМУ ВЧЕННІ

\section{В.В. ЗЕНЬКОВСЬКОГО}

У статті представлене дослідження концепту «цілісної особистості» в християнській антропології вітчизняного філософа-богослова та психолога В.В. Зеньковського. Розглядаються різні аспекти духовності людини які базуються на системі таких понять як цілісність, Образ Божий та свобода людини. Окремо представлено аналіз прощесу побудови християнської моделі цілісної людини в творчості В. В. Зеньковського.

Ключові слова: цілісність, духовність, особистість, християнська антропологія.

Захарина М.А. Концепт «целостной личности» в фбллософбском учении В.В. Зеньковского.

В статье исследуется концепт «целостной личности» в христианской антропологии отечественного философа-богослова и психолога В.В. Зеньковского. Рассматриваются различные аспекты духовности человека, которые базируються на системе таких понятий как целостность, Образ Божий и свобода человека. Отдельно представлено аналіз процесса построения христианской модели целостного человека в творчестве $B$. В. Зеньковского.

Ключевые слова: целостность, духовность, личность, христианская антропология.

M. I. Zakharina. The concept of "integral personality" in Zenkovsky's philosophical doctrine.

The paper examines the concept of "whole person» in Christian anthropology of philosopher, theologian, psychologist V. V. Zenkivskyi. 